\title{
BEKAMPING VAN STOF VEROORSAAK DEUR MYNBOUBEDRYWIGHEDE
}

\author{
J.M.O. Van Sittert \\ Hoofinspekteur van Myne, Omgewingsbeheer (Myne en Bedrywe) \\ Departement van Mineraal- en Energiesake
}

Hierdie referaat is gelewer tydens die byeenkoms van lugbesoedelingsbeheerbeamptes in diens van plaaslike besture in Transvaal op 6 September, 1984, te Alberton.

1. Die onderwerp van stofbekamping is so wyd dat 'n mens kwalik in die bestek van 30 minute 'n tegniese verhandeling daaroor kan lewer. Ek is dus van plan om vir die volgende halfuur in the algemeen oor stof en die bekamping daarvan te praat.

2. Wat is stof?

Stof kan gedefinieer word as fyn verpulwerde deeltjies van vaste materie, in 'n rustende of swewende staat. Stof uit 'n lugbesoedelingsoogpunt kan gedefinieer word as die partikulêre komponent in die atmosfeer wat onwenslik is vir die mens en sy omgewing. Hierdie vaste stofdeeltjies kan in drie groottes geklassifiseer word, vol klonte (behalwe bakstene!) +50 mikrometer, Stof $2-50$ mikrometer en damp - 2 mikrometer.

Vir alle praktiese doeleindes kan stof egter as volg ingedeel word:

2.1 Inasembare sweefstof wat 'n gesondheidsrisiko inhou. Hierdie is stof in die grootte-bestek 0,5 mikrometer tot 7 mikrometer.

2.2 Stof met 'n lastigheidswaarde (of oorlaswaarde): Dit is natuurlik alle sweefstof wat groter as 7 mikrometer is en wat swewend is.

Stof in hierdie kategorie, veral dié groter as 30 mikrometer, kan 'n baie nadelige uitwerking op Elektriese en meganiese toerusting hê. Kontrakteurs wat vervoerwerk op mynsandhope doen moes uit dure ondervinding leer dat hierdie tipe stof gemeng met olie of ghries, 'n baie doeltreffende skuurpoeier (grinding paste) vorm! Stof in die bestek 7 mikrometer en 30 mikrometer, is natuurlik hoofsaaklik daarvoor verantwoordelik dat ons hele habitat so erg besmeer word!

Dit is dus duidelik dat inasembare sweefstof wat die longe kan binnedring nie met die blote oog gesien kan word nie. Dit wat gesien kan word het net 'n lastigheidswaarde. Wat egter belangrik is om te weet is dat indien daar sigbare stofdeeltjies in die atmosfeer is, daar gewoonlik baie meer onsigbare sweefstofdeeltjies teenwoordig is.

3. Die Gevare van stof

Siektes wat deur inasembare sweefstof veroorsaak word, sluit die volgende in:
3.1 Verstopte lugweë.

3.2 Pneumokoniose, 'n permanente siekte van die longe wat silikose, asbestose en steenkoolpneumokoniose insluit.

3.3 Asbesvesel kan ook kwaadaarigde siektes soos longkanker of mesotelioom tot gevolg hê.

Dit is interessant om te lees dat die 1984 uitgawe van die publikasie van "The Institute of Occupational Medicine" beweer (vry vertaal) "dat die inaseming van sweefstof nie net pneumokoniose veroorsaak nie, maar dat dit 'n mens se risiko verhoog vir die ontwikkeling van hoes, slym en die potensiële belemmerende siekte kroniese verstopping van die lugweë. In die geval van blootstellings aan lae konsentrasies sal die effek klein wees, miskien baie minder as die gevolge van sigaretrook, maar studies het 'n subgroep van mense geidentifiseer wat baie ongunstig gereageer het op stofblootstelling.

4. Oorsprong van stof

Die oorsprong of bron van stof is onbeperk. Enigiemand wat weet hoe 'n mens 'n baie kort persoon beskryf sal besef dat dit nie veel vat om 'n stofwolk te veroorsaak nie!

Vir hierdie praatjie sal ek my egter by stof wat deur Myne en Bedrywe veroorsaak word beperk, waar die hoofbronne van stof die volgende is:-

4.1 Waar klip of erts vergruis, vermeng of vervoer word, soos by groewe.

4.2 Waar afvalmateriaal gestort word, of herwin word, soos by sandhope en slikdamme.

Die hoeveelheid stof wat deur laasgenoemde veroorsaak word hang van verskeie faktore af. Die belangrikste is sekerlik die tipe materiaal wat verwerk word asook die metode van verwerking.

5. Stofbekamping

In breë trekke sal stofbekamping onder die volgende hoofde bespreek word:-

Algemeen, Myne, Sandhope en slikdamme.

5.1 Die enigste doeltreffende metode van stofbekamping is by die bron, en hier geld die ou beginsel van "voorkoming is beter as genesing". 
Daar moet altyd getrag word om te verhoed dat stof geproduseer word al behels dit soms die verandering van ' $n$ basiese proses.

Indien die produksie van stof egter onvermydelik is moet dit by die bron beheer word deur suigstelsels waarna dit dan onder andere deur middel van filtreerders opgevang kan word. Wat die verskillende tipes filtreerders betref $\mathrm{kan}$ die volgende breë beginsels neergelê word:-

5.1.1 Vir stofdeeltjies van 0,001 mikrometer tot 50 mikrometer kan Elektrostatiese presipiteerders gebruik word.

5.1.2 Doekversamelaars of sakfilters van verskillende materiale is baie doeltreffend vir stofdeeltjies in die groottebestek 0,01 mikrometer tot 100 mikrometer.

5.1.3 Natversamelaars of Waterskroppers word normaalweg gebruik vir stofdeeltjies tussen 1 mikrometer en 100 mikrometer.

5.1.4 Vir stofdeeltjies groter as 10 mikrometer is siklone baie doeltreffend, terwyl besinkingskamers gebruik word vir stofdeeltjies groter as 100 mikrometer.

\subsection{Stofbekamping by myne}

5.2.1 Met die hedendaagse tegnologie van stofvoorkoming is die stofprobleem in ondergrondse werksplekke grootliks opgelos en vergelyk toestande met die beste ter wêreld. Die enigste uitsondering is by meganiese delwers in steenkoolmyne wat tans baie aandag geniet. Een van die faktore wat stofbekamping in ondergrondse werksplekke vergemaklik is die feit dat daar in 'n beperkte ruimte gewerk word, wat die onttrekking en suiwering van lug vergemaklik.

5.2.2 By oopgroefmyne is stofbeheer egter 'n perd van ' $n$ ander kleur en bekampingsmaatreëls is die volgende:-

5.2.2.1 Waar klip of erts vergruis, geklassifiseer, vermeng of verskuif word moet dit nat gehou word en van uitsuigstelsels met geskikte filtreerders voorsien word.

5.2.2.2 Alle paaie by die groewe en aanlegte moet ten alle tye nat gehou word, deur byvoorbeeld permanente watersproeiers of mobiele waterkarre. Hierdie maatreëls geld ook vir voorraadstapels.

5.2.2.3 'n Groot bron van lugbesoedeling wat altyd 'n twisappel tussen 'n oopgroef- mynbestuurder en sy bure is, is die stof en rook veroorsaak deur skietwerk. Hierdie stof kan egter beperk word deur skietwerk te beperk tot sê een of twee keer per week, met in agneming van heersende winde en weerstoestande. Die beheer van die hoeveelheid plofstof en die breeklading per gelaaide gat speel ook 'n groot rol.

\subsection{Sandhope en Slikdamme}

Hierdie afvalhope van die goudmynbedryf is al sedert 1886 'n bron van lugbesoedelingan die Witwatersrand. Gedurende die vyftiger jare het die probleem akuut geword en dit was duidelik dat iets drasties gedoen moes word. Sedert 1963 is die Begrassingseenheid van die Kamer van Mynwese doelgerig besig met die vestiging van plantegroei op sandhope en slikdamme.

5.3.1 Langtermyn bekamping van stof by uitskothope.

Intensiewe navorsing om alternatiewe metodes soos byvoorbeeld verharding te ondersoek word onderneem maar vestiging van plantegroei word nog allerweë as die suksesvolste metode vir langtermyn besoedelingsbeheer beskou.

Die verskillende metodes wat tans toegepas word, word kortliks bespreek:

\subsubsection{Slikdamme:}

Die natuurlike hardheidsgraad van die damme se oppervlak word met 'n spesiaal ontwerpte instrumentbepaal. Normaalweg verhard die sykante van slikdamme sodanig dat dit geen aandag vereis nie. Die boonste oppervlak (of kruin), moet egter gewoonlik behandel word.

Die suurgehalte van die uitskot materiaal word eers bepaal sodat daar besluit kan word of van droëland landboumetodes gebruik gemaak kan word, en, of uitloging deur water eers gedoen moet word.

Indien van droëlandmetodes gebruik gemaak word, word groot hoeveelhede landboukalk (tot 7 ton per hektaar) toegedien en dan sowat 8 $\mathrm{cm}$ diep ingewerk. 'n Mengsel van grassaad word dan gesaai terwyl ongeveer $300 \mathrm{~kg}$ per hektaar superfosfaat bygevoeg word. Die saadbed word lig gerol en 'n 2.3.2 kunsmis 
word teen $300 \mathrm{~kg}$ per hektaar van tyd tot tyd toegedien. Omtrent 'n maand na ontkieming word $\pm 50 \mathrm{~kg}$ per hektaar ureum gestrooi.

Die hellings van slikdamme en kruine waar die PH waarde te laag is word basies op dieselfde manier behandel, nadat die suur uitgeloog is. Waar groot spoelslote voorkom, word van stootskrapers en ander swaar toerusting gebruik gemaak om dit op te vul. 'n Netwerk van plastiese waterpype word dan \pm 3 meter uitmekaar gelê en toegerus met spuitpunte. Die hele gebied word dan met veldgras bedek en die uitloging van die suur deur die toediening van groot hoeveelhede water voortgesit totdat die suurgehalte die gewenste vlak bereik het. Hierna kan met die saai van plantmateriaal voortgegaan word soos met die droëland metode. Die uitlogingstoerusting word met standaard besproeiingstoerusting vervang nadat plantegroei goed gevestig is.

\subsubsection{Sandhope}

Die enigste verskil tussen die behandeling van slikdamme en sandhope is dat sandverskuiwing deur wind en water beheer moet word deur die oprigting van windskerms. Dit word gedoen deur vleiriet in vakke aan te bring:

\section{$15 \mathrm{~cm}$ diep en ongeveer $0,7 \mathrm{~m}$ hoog.}

Dit mag ook nodig wees om die helling van sandhope met swaartoerusting af te plat tot die natuurlike hellingshoek van $37^{\circ}$.

5.3.2 Die koste verbonde aan die vestiging van plantegroei op mynhope bedra tans tussen R22 000 en R25 000 per hektaar, terwyl nasorg, in die vorm van die strooi van kunsmis 'n bedrag van ongeveer R200 per hektaar per jaar bedra.

5.3.3 Korttermyn bekamping van stof by mynhope 'n Groot bron van lugbesoedeling wat die hoof gebied moet word, is mynhope wat herbewerk word vir die herwinning van goud, of wat binnekort weer verwerk gaan word, en waar die hoë koste van plantvestiging nie geregverdig is nie. 'n Praktiese probleem in dié verband is ook die algemene tekort aan water in die probleemgebiede.

Die metode wat hedendaags vinnig veld wen en wat skynbaar 'n korttermynoplossing bied, is die aanwending van Chemikalieë wat verharding van die bolaag teweegbring. Eksperimente het bewys dat van die stowwe, hetsy dit 'n harde lagie of 'n elastiese bedekking vorm, reën en windbestand is, en vir tydperke van tot agtien maande doeltreffend bly. Teen R1 600 per hektaar mag dit na 'n duur transaksie klink, veral as mens in ag neem dat dit soms net vir twee weke ingebruik is voordat sodanige behandelde gedeelte weer weggewerk word. Dit is egter my beskeie mening dat geen herwinningsproses goedkoop gehou mag word ten koste van skoon lug nie.

\section{QUO VADIS?}

Die laaste woord oor stofbekamping is nog lank nie gespreek nie, inteendeel, die veld lê nog braak. Wat die vestiging van plantegroei aanbetref word daar tans met hernude ywer gekyk na die vestiging van effektiewe selfonderhoudende, inheemse plantbedekking ten einde die versteurde ekologie te herstel. Die vestiging van kruide, struike, en bome, veral dié wat vrugte en bessies dra, sal aandag geniet, sodat insek-, voël-en dierelewe bevorder kan word. Die moontlikheid van beweiding van aangeplante gras kan ook oorweeg word, wat natuurlik voortplanting sal aanhelp en ook sal verhoed dat veldbrande nie met so 'n intense hitte gepaard gaan dat permanente wortelbeskadiging sal plaasvind nie.

Aan vindingrykheid ontbreek dit nie en met die nodige ywer en met toewyding van alle belanghebbendes behoort daarin geslaag te word om die gesigseinders helder en die hemel blou te hou! 